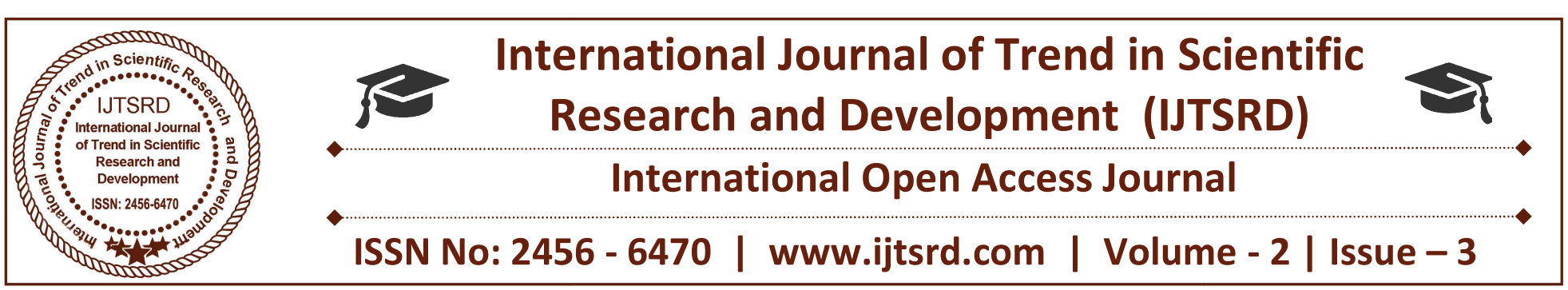

\title{
Understanding the Institution of Syiemship(Kingship) in the Khasi Hills of Meghalaya Through Oral Traditions
}

\author{
Ms Ibetlin Kharumnuid
}

Assistant Professor, Department of History, Seng Khasi College, Shillong, Meghalaya, India

\begin{abstract}
The origin of the Khasis and how they came to settled in these regions is shrouded in mystery. While social scientists believed that the Khasi settlers had connections or a close resemblance with the Chinese and had migrated to the present lands and therefore had Austric links, legends had it that the original seven families or Hynniewtrep descended by a golden ladder from the heavens and decided to stay back on earth and start their settlements.

Since the beginning the people were very sure about making these hills their permanent home. They decided upon an elderly person to become some sort of a priest (Lyngdoh Knia) to look after the wellbeing of the people inhabiting the region. For this selection, the ritual of egg breaking (shat pylleng) was considered to be the best way by which they could find the right person.
\end{abstract}

In the beginning, there was no institution of Syiemship (Kingship), but people comprehended about the need to have at least one leader to look after their welfare. Basan and a Lyngdoh were chosen as leaders to administer the village community and attempted to bring the different villages together. After the Khasis had made their settlements, they decided they would choose among themselves the eldest male member to be their ruler and administrator, the emergence of such States or settlements led to the origin of the institution of Syiemship(Kingship), thus originated the concept of U Syiem (The King).

The origin of the Khasi Syiem shows that initially there were three large Syiemships(Kingship) which later increases over time with large and small Syiemships. Syiemships having mythological origin like those of Khyrim, Malngaing and even the Sutnga Syiem were considered divine.

The institution of the Khyrim Syiemship dates back to the legend of Ka-Pah-Syntiew. Oral traditions stated that the Hima Shyllong as being of divine origin, and that the ancestress of the clan is a fairy (Puriblei) that lived in a cave called Krem Marai.

Keywords: Khasis, Basan, Lyngdoh, U Syiem(The King), Ka-Pah-Syntiew, Puriblei

\section{INTRODUCTION}

The origin of the Khasis and how they came to settled in these regions is shrouded in mystery. While social scientists believed that the Khasi settlers had connections or a close resemblance with the Chinese and had migrated to the present lands and therefore had Austric links, legends had it that the original seven families or Hynniewtrep descended by a golden ladder from the heavens and decided to stay back on earth and start their settlements ${ }^{1,2}$.

Initially, at the beginning of State formation, though few in number, the people were very sure about making that settlement their permanent home. They then decided upon an elderly person to become some sort of a priest (Lyngdoh Knia) to look after the wellbeing of the people inhabiting the region. For this selection, the ritual of egg breaking (shat pylleng) was considered to be the best way by which they could find the right person ${ }^{3}$. Thus in the beginning of Khasi 
settlements, there was no institution of Syiemship (Kingship), though people had by then comprehend about the need to have at least one leader with the sole responsibility of looking and deciding about their welfare.

\section{EVOLUTION OF SYIEMSHIP (KINGSHIP)}

Khasi polity has had an age along evolution. The political organizations had developed right from the time of the earliest settlements to the period prior to the formation of Syiemship (Kingship). Basan and a Lyngdoh were chosen as leaders to administer the village community and attempted to bring the different village's together ${ }^{4}$. When the Khasis had made their settlements, they decided they would choose among themselves the eldest male member to be their ruler and administrator so that, the society and state could get the respect from other inhabitants.

Religion was always a part of the daily life of a Khasi. For every activity or work to be done, the Khasi offered their prayers first. Having been settled in a particular place, the inhabitant thought of having a person who would be entrusted with the affairs of the people both administrative and sacerdotal and this necessity led to the establishment of the Lyngdoh or priest. In case of any misunderstanding among the people the Lyngdoh intervene by resorting to religious rights and rituals. On the other hand, the people were always ready to accept whatever decisions which were being made for fear that may displease the gods, if they go against the decisions of the Lyngdoh and thus calamity may be fall upon them. The Lyngdohs were thus the actual rulers as well as the sacerdotal heads and were aided by a council of Basans consisting of the representatives of respective clans in executive function and other related activities for the general welfare of the community ${ }^{5}$.

\section{ESTABLISHMENTS OF SYIEMSHIP (KINGSHIP)}

The emergence of such States or settlements led to the origin of the institution of Syiemship. Thus they sat together and decided that they should nominate a person who would be a custodian of the people and to give him due honour and respect and thus originated the concept of U Syiem (The King). ${ }^{6}$ Inorder that the institution of Syiemship should gather in strength and popularity, it was thought desirable that some ways should be devised by which such a leader or ruler administrator be found. The office of Syiem thus emanated as an institution to centralize the administration and also to look into the welfare of the Hima (State). It was in this order that the formative phase in Syiemship had to undergo many challenges and changes. The institution of Syiemship meant that the earlier Khasi polity had to be done away with and so also to some extent the administration of the Basan and the Lyngdoh.

The institution of Syiemship (Kingship) was symbolized by the unions of clans, villages and communes which had made up a community in the settlements. The word Syiem is derived from the word mynsiem literally meaning spirit, a rallying point of spiritual fellowship of people called KiKhun Ki-Hajar which means children. This would lead us to believe that the Syiem (King) was someone whom everyone would turn to when they fell into trouble. According to tradition, a Syiem should be proficient enough to carry out the administration in the interests of the people and he was to receive adequate training in the art of administration. In course of time the Syiems had to also be proficient in the art of warfare.

Tradition says that more often than not, a person would refrain from being Conferred the title of Syiem, as the leadership pattern in the form of Syiem was taken to be a despised one. This may be due to the unusual duties which U Syiem had to perform, he was to clear and cremate the death bodies of strangers or wanderers in his dominions; he was to suppress the practice of witchcraft and magic and to drive away infectious evils. Not being allowed to carry on any profession the Syiem would have to maintain himself only from the paltry sum of revenue which was collected from markets. Strangely enough, in the beginning, few accepted this position and status ${ }^{7}$.

A study of the origin of the Khasi Syiems shows that there were various classifications of Syiems. Syiemship (Kingship) having mythological origin were considered to be Syiem Blei (Syiem means King and Blei means God) or Syiem of Divine Origin. There was also the Syiem Mraw (Syiem means King and Mraw means slave) or Slave Kings who were kidnapped from the plains and anointed as Syiems like the Syiem of Hima Mawiang. Syiems of the more recent date are called Syiem-briew (Syiem means King and Briew means human) or manmade Syiems. As the Syiem of Mylliem was not required to perform many of the rites and ceremonies, 
which, one can say, the Syiem of Khyrim, had to perform, they are known as Syiem-briew ${ }^{8,9}$.

A study of the origin of the Khasi Syiem(Khasi Kings) shows that initially there were three large Syiemships (Kingship) which later increases as developments took place over time with large and small Syiemships. Syiemships having mythological origin like those of Khyrim, Malngaing and even the Sutnga Syiem were considered divine.

The institution of the Khyrim Syiemship dates back to the legend of Ka-Pah-Syntiew. Homiwell Lyngdoh in his book "Ki Syiem Khasi bad Synteng" mentions about oral traditions which stated that the Hima Shyllong as being of divine origin, and that the ancestress of the clan is a fairy (Puriblei) that lived in a cave called Krem Marai (Krem means cave and Marai is the name of the cave).

Legends have it that before the beginning of Ka Hima Shyllong, the lands surrounding U Lum Shyllong were under the administration of leaders who belonged to the founding clans (jait Bakhraw). In those days, as legends goes, there were cowherds who would go to the river valley of Wah Umiew(River Umiew) to tend to their herds and cattle's. The young boys narrated that they would often see a young maiden who would sit on a huge rock, and that she was so beautiful. Whenever they try to go near her, she would climb down the boulder and go back to her cave which is below the boulder. When more and more peoples heard about the beauty of this mysterious maiden, person would visit the place, but none would dare venture into the cave. Then one day a young man from the Mylliemngap clan decided to visit the place and thought of a plan to lure her out of the cave. (Another version holds that it was a young man from the Bhoi area, called Nongjri Kongor). The young man collected a bunch of flowers named jalyngkteng (tiew jalyngkteng) and held it at the mouth of the cave. The young maiden was attracted by the bunch of flowers and came to the mouth of the cave but when she tried to reach out for the flowers, the young man would move his hand back a little. The young maiden would again try to reach for the flowers and again the Mylliemngap man would recede backwards. The process would repeat again and again till finally the young maiden was out of the cave and into the open. At this moment the man took his chance and caught hold of the maiden and took her home to his mother. Rites and rituals were performed and the family of $\mathbf{U}$ Mylliemngap took care of her like a daughter. They called her "Ka Pah Syntiew"( Pah means lure and Syntiew means flowers) because she was lured out of her cave by a bunch of flowers. Ka Pah Syntiew grew up to be a very beautiful, kind-hearted lady and everyone loved and adored her. When the time came for Ka Pah Syntiew to get married, the Mylliemngap clan arranged her marriage with a young man called " $U$ Kongor Nongjri" ${ }^{10}$.

Ka Pah Syntiew gave birth to two sons and a daughter, and after they had grown up a bit, she left her family and returned back to her cave "Ka Krem Marai" never to come out again. The children of Ka Pah Syntiew and $\mathbf{U}$ Kongor Nongjri, were considered to be the children of the Gods (Khun-blei) as $\mathrm{Ka} \mathrm{Pah}$ Syntiew herself was considered the daughter of the mountain God -U Lei Shillong( Lei means God and Shillong is the name of the mountain). In course of time, the story of courage, wisdom and humility of the two sons of $\mathrm{Ka} \mathrm{Pah}$ Syntiew spread around, the leaders of the settlements in and around $\mathbf{U}$ Lum Shillong, held a Durbar and decided that they would unite together to form one Him(State) and that they would elect the Children of Ka Pah Syntiew to be their "Syiem"(King) because of their Divine Origin. Thus came about Ka Hima Shyllong(State of Shillong).

Another version of the legend stated that she was the daughter of a Bhoi Nongsohbar who lived in Bisi. When this man came to know that his wife committed adultery, he sent her out of her home. This young girl followed her mother who travelled towards Wah Umiam/Umiew(River Umiammiew). On reaching there, she placed her daughter on the rock and she herself went to bathe in the river. The strong current of the river swept her away. In the evening when her mother did not return, the little girl came down the rock and stayed in the cave till she was rescued by the man from the Mylliemngap clan ${ }^{11}$.

Still another version of the legend stated that she was one of the two young maidens who were seen on top of a boulder near the cave. Many people requested them to come down but they refused. Finally a woman from the Mylliemngap clan lured them with a bunch of beautiful flowers, where one of the maiden agreed to come down and went and lived with her in Bisi ${ }^{12}$.

Whatever the legends goes, it shows that there was a young maiden who was lured out of the cave (Ka 
Krem Marai) by a bunch of flowers and was called Ka Pah Syntiew.

Legends do not say the names of the sons of Ka Pah Syntiew who became the first Syiems of Hima Shyllong. But over the years, there started misunderstandings and conflicts within the Syiemship which eventually would lead to a division in the Syiemship and the formation of Ka Hima Khyrim(State of Khyrim) and Ka Hima Mylliem(State of Mylliem) in the year 1853. The Syiems of Ka Hima Khyrim till date performs the religious rites and ceremonies which gives credence to their being of divine origin according to legends and folklore ${ }^{13}$.

\section{CONCLUSION}

In understanding the institution of Syiemship (Kingship) of the Khasi States, oral traditions through myths, legends and folklore form the main source of information. The interpretation of these oral sources may vary from one to another. However they provided sufficient legitimation to the origin of Syiemship.

\section{REFERENCES}

1. H. Lyngdoh, Ka Niam Khasi: 2-4

2. JN Choudhury, Ki Khun Khasi Khara (The Khasi people): 28

3. G. Costa, Ka Riti jong ka Ri Laiphew Syiem I: 103

4. G. Costa, Ka Riti jong ka Ri Laiphew Syiem I: 109

5. G. Costa, Ka Riti jong ka Ri Laiphew Syiem I: 11

6. G. Costa, Ka Riti jong ka Ri Laiphew Syiem I:109

7. H.Bareh, History and culture of the Khasi people: 42

8. L.S. Gassah. Lest We Forget: 13

9. D.R. syiemlieh, British Administration in Meghalaya policy and pattern: 66

10. U Homiwell Lyngdoh, Ki Syiem Khasi bad Synteng: 84

11. U Homiwell Lyngdoh, Ki Syiem Khasi bad Synteng: 86

12. U Homiwell Lyngdoh, Ki Syiem Khasi bad Synteng: 86

13. U Homiwell Lyngdoh, Ki Syiem Khasi bad Synteng: 89 